out at temperatures up to $160^{\circ} \mathrm{C}$. using 100,000 blows from a modified Stanton impact testing machine as standard.

The results published in these papers represent a preliminary survey of the mechanical properties of white bearing metals which is essential if the effect on the standard alloys of other additions is to be measured. The work, which has been carried out in the Metallurgical Department of the University of Manchester, has been rendered possible by financial assistance from the International Tin Research and Development Council, and is, even in its present stage, one of the most comprehensive examinations of these alloys which has yet been undertaken. F. C. T.

\section{The Origins of Plankton}

$I^{\mathrm{N}}$ the course of a discussion on the "Biological Problems of Fresh Water" before a joint meeting of Sections D and $K$ of the British Association at Aberdeen (Nature, Sept. 22, p. 467), Prof. F. E. Fritsch pointed out that one of the outstanding problems confronting workers in this field is that of discovering the origins of the many recurrent cycles of free-floating organisms (plants and animals) that occur in the surface layers of standing waters and at times populate them in such enormous numbers that they lend a definite colour to the water.

Such populations, constituting the plankton, often last only for a few weeks and then vanish completely, only to reappear each year usually at approximately the same time. They are often a source of considerable trouble in reservoirs. On the other hand, the plankton is also of great economic importance in that, directly or indirectly, it constitutes an important part of the food-supply of fish.

A small number of the manifold plants (algæ) of the plankton, at the end of their period of abundance, form special resting-stages (spores) which gradually sink to the bottom or into the deeper waters, but there is no evidence that this is of general occurrence. Most species must persist from one season to the next in the form of occasional unaltered individuals. The problem at issue is whether such persisting individuals and spores remain viable wherever they are deposited, or whether it is only those that settle in the shallower waters round the banks that retain their vitality and give rise to a fresh crop in the next season. It is known that some of the diatoms of the plankton are bred in the shore waters and from there gradually spread into the general body, but for the vast majority of plankton algæ there is no evidence that this happens, and it is likely that many are derived from spores or persisting individuals which have lain dormant at the bottom under the deeper waters during their period of absence from the surface layers. This is particularly likely to be true of the numerous blue-green algæ of the plankton. These forms owe their buoyancy to the development of minute cavities, containing gases, in the protoplasm of their cells. Continental workers have found some evidence that these so-called gas-vacuoles are a result of the fermentation processes which are believed to take place in the cells in the absence of oxygen, when such forms-either as individuals or spores-are resting at the bottom. The production of gas renders them buoyant so that they float to the surface and appear in the plankton, while new spores which lack the gas-vacuoles are heavier than water and again sink to the bottom.

It is thus probable that the plants of the plankton are recruited from two sources, in part from restingstages or persisting individuals lying on the bottom under the deeper waters, and in part from similar stages that survive near the banks. The degree of importance of the latter element will depend on the extent of the shallow water near the banks and the facilities for the distribution of the forms growing there into the open water.

Much detailed research is still requisite before precise knowledge on these matters is available, research which is of fundamental importance in all aquatic biological investigations. G. A.S.

\section{University and Educational Intelligence}

Cambridge.-J. S. Turner of Selwyn College has been appointed University demonstrator in botany.

L. J. Audus of Downing College has been appointed to the Frank Smart University studentship in botany.

At Queens' College the following have been elected into reserved fellowships :-F. Goldby of Gonville and Caius College, University demonstrator in anatomy; J. A. Ramsay of Gonville and Caius College. At Downing College, E. B. Verney, Shield reader in pharmacology, has been elected into a professorial fellowship.

Leeps.-Dr. L. H. Stickland has been appointed biochemist in the Cancer Research Laboratories, in succession to Dr. Havard, who has resigned.

London.-The Surrey County Council has decided to make a grant of $£ 50,000$, payable over ten years and subject to the approval by the County Council each year of the inclusion of the amount in the annual estimates, towards the erection of the University buildings in Bloomsbury. A grant towards the same purpose of $£ 10,000$, payable over ten years, has also been made by the Hertfordshire County Council. The Worshipful Company of Turners has made a donation towards the Ceremonial Hall.

Forergn students in the United States in 1931 numbered more than eight thousand according to a report recently published by the Federal Office of Education, as Pamphlet No. 48 on "Residence and Migration of College Students". A similar report published in 1926 as Bulletin No. 11 gave the number of foreign students in 1923 as 6,692. Although the two sets of statistics are not strictly comparable, it seems clear that there has been a substantial increase in the number of students resorting to the United States from other countries for post-secondary edu. cation and for research. Analysing the figures according to the students' home-residence, one finds noticeable increases under Canada (from 1,251 to 1,896), Mexico (298 to 402), Central America (118 to 187), Colombia (40 to 67), Scotland (26 to 55), Ireland (32 to 59 ), Belgium (30 to 51) and Italy (35 to 82), but decreases under China (1,605 to 1,317 ), Japan (583 to 502), India (288 to 235), Russia (190 to 153), South Africa (130 to 73), Argentina (51 to 29 ), Chile $(60$ to 36 ) and Peru (54 to 25). 